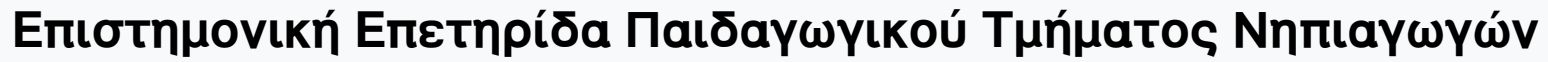

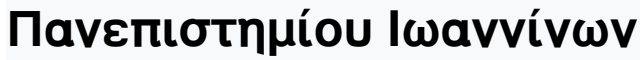

\author{
Tóp. 9, Ap. 2 (2016)
}

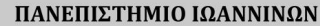

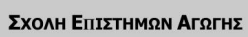

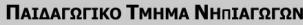

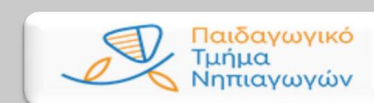

Nnriaywywiv

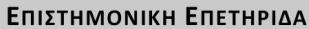

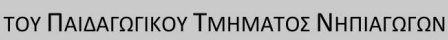

JOURNAL OF RESEARCH IN EDUCATION AND TRAINING

DEPARTMENT OF EARLY CHILDHOOD EDUCATION

TOMOг $9-$ VOL 9

APIOMOE 2- NO 2

2016
"Some(where)...Some(how)...Some(time)". Detecting elements of racist ideology by analyzing the time and space of narrative.

Theodora Koutziakoutzidou

doi: $10.12681 /$ jret.8691

Copyright ( 2016, OEO $\triangle$ SPA ANA $\Sigma T A \Sigma I O \Sigma$ KOYTZIAKOYTZI $\triangle O Y$

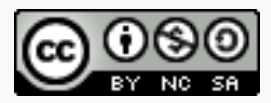

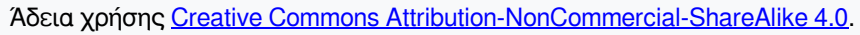

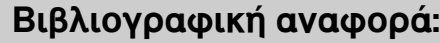

Koutziakoutzidou, T. (2016). "Some(where)...Some(how)...Some(time)". Detecting elements of racist ideology by

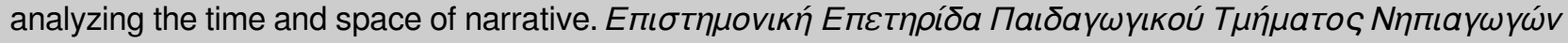

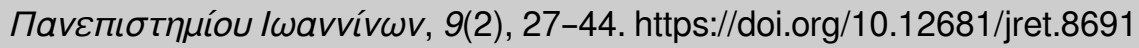




\title{
"Some (where)...Some(how)...Some(time)". Detecting elements of racist ideology by analyzing the time and space of narrative.
}

\author{
Dr. Koutziakoutzidou Theodora ${ }^{1}$ \\ ${ }^{1}$ Pre-School Teacher
}

\begin{abstract}
The aim of this paper is to analyze time and space of narration in two illustrated books, "A Special Friend-it all started with a yellow bike" (2010) by Anny Theochari, illustrated by Willy Karabatzia, and "The most beautiful drawing by Marina" (2006) by Katerina Papanikolopoulou and illustrated by Niki Leonidou. In the study of texts of children's literature, space and time constitute an important parameter, since they both directly affect the young reader's response.Firstly, we will refer to theoretical considerations on the narrative analysis of time and space, using a combination of methodological tools. We will examine the narrative techniques found in the texts, according to the theory of Genette, focusing on the time of narration, the sequence of events and the relationship between the time of history to the time of narration. We will also use the methodology proposed by the theory of Imagology, which we adapted taking into account the specificity of the texts under discussion of our analysis. In particular, we focused on the field of investigating the space of the "other". Our aim is to identify and study the contrast noted when comparing the "familiar" space with the space of the "other". This will offer us an analytical tool to detect evidence of racist ideology, which may help decode the stereotypical images that often acquaint the child reader with the world of the "different". Illustrated books are considered very important and play a decisive role in shaping a child's personality. Moreover, illustrated books often express the ideologies of authors and illustrators, directly or indirectly, consciously or unconsciously, as they carry ideas and ideological thesis.
\end{abstract}

Key-words: ideology, illustrated books, Imagology, Other, racism, Narratology, Children's literature 


\section{Introduction}

In this paper, we will analyze the space of the "other" and the time of narration in two illustrated books addressed to young children and first year primary school readers. We will examine the texts' narrative techniques, according to the Genette's theory, focusing on the time of narration, the sequence of events, the relationship between the time of history, and the time of narration. For the analysis of space we have applied the methodology proposed by the theory of Imagology proposed by Francesca Ambatzopoulou. In our case, we focused on the field of investigating the space of the "other". In addition, through the analysis of the space of the "other" we tried to study contrasts descriptions of "familiar", in order to detect evidence of racist ideology. More precisely what we want to bring in, concerns the aspect from which we will approach the issue of racism, which can be identified in children's book in a number of ways ${ }^{1}$.

In the first illustrated story, entitled "A special friend-it all started with a yellow bike" (2010) by Anny Theochari, we focus on the social aspect of racism, on social exclusion and particularly on the rejection-marginalization of a child from their peers, and from the games played between their peers.

In the second illustrated story, entitled, "The most beautiful drawing by Marina" (2006) by Katerina Papanikolopoulou, we focus on the difficulties children face in adjusting to a new environment, either a new school or country. In addition, in the context of these situations, we have referred to a third well- known story from Greece, "And the stories immigrate" (2010) by Vangelis Iliopoulos, the protagonist of which is facing similar difficulties upon immigrating into a new country.

In this paper, in the first case we focus on physical disabilities, which lead to phenomena of school exclusion and marginalization, and in the second case, on situations of adaptation to a new environment. Both stories are dramatized in a frame of school reality, and both highlight the value of friendship and the importance of games in children's everyday school life.

\footnotetext{
${ }^{1}$ Marshall, M., An Introduction to World of Children's Books, $2^{\text {nd }}$ edition, Gower, Ashgate, $1988, \sigma .42$.
} 
Children's literature, is one of the most essential "tools" leading to social awareness on issues of racism and social exclusion, and this has to do a lot with issues related to attitudes towards the "other". It is of utmost importance that we raise awareness among young readers towards the necessity of respecting and accepting "otherness".

A great number of illustrated books are created on specific situations, and often raise social issues ${ }^{2}$. Through fictional situations, the reader-child can be prepared for life, by exploring the fictional world. Because these stories happen in another place and time, children may identify, with heroes from books without feelings of guilt ${ }^{3}$. The pictures in the case of the illustrated books play an important and integral part in narration, at least equal in expressive power to the text itself ${ }^{4}$. Apart from the decorative, descriptive and narrative character, pictures quite often manage to function as a mirror which decodes and encodes faces, emotions and situations and gives the child-reader a new view of situations, enabling their capacity for critical thinking. Moreover, illustrations in books can facilitate the reader's comprehension, identification, and experience ${ }^{5}$.

No work, even the most apparently simple book for children, can be without ideology ${ }^{6}$. This view also prevails amongst Greek critics and scholars of children's literature. According to Kallergis, «Ideology is simply a belief system that expresses an understanding of the world and history through the eyes of a group, a class or a political party. The words «carry perceptions and prejudices, create social language

\footnotetext{
${ }^{2}$ Nodelman, P., Words about pictures. The Narrative Art of Children's Picture Books, Athens and London: The University of Georgia Press, 1988, б.1.

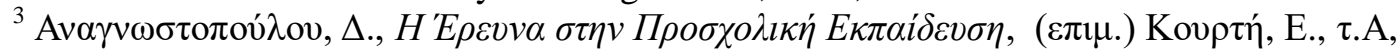
A $\theta \dot{v} v \alpha:$ Tv $\omega \omega \theta \dot{\tau} \tau \omega, 2001, \sigma \sigma .118-119$.

${ }^{4}$ Norton, D., Through the eyes of a child: An Introduction to Children's Literature, Columbus

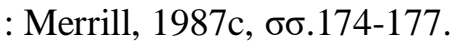

${ }^{5}$ Ciancolo, P., Illustrations in Children's Books, Dubuque, Iowa, WM.C Brown Company

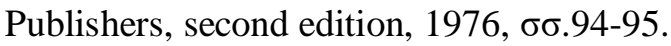

${ }^{6}$ Hunt, P., Literature for Children, Contemporary Criticism, London: Routledge, $\sigma .18$.
} 
expressing the worldview of social groups ${ }^{7} \gg$. In this vain Hollindale also argues that, «no literature is not without ideological charge ${ }^{8} »$.

In the era of globalization we are experiencing today, the huge debates on diversity that have come to the spotlight could not leave children's literature unaffected, since the latter -as mentioned above- draws its topics and themes from both reality and current social issues, and recreates them in texts and other media for children. As Kanatsouli asserts: "Literary books can be a means, through which attitudes are shaped, values are passed on to the next generation and behavioral models-that influence the views,beliefs and choices of a person, are also carried on ${ }^{9} \gg$. Children's literature capturing social phenomena «constitutes one of the main means affecting the social sensitization of children on issues of racism (racial and social) and social exclusion» ${ }^{10}$.

\section{Methodology}

Undoubtedly, one of the major epistemological currents that influenced the theoretical thinking of the $20^{\text {th }}$ century is structuralism, as is evident in almost all fields of human sciences, from anthropology to psychoanalysis, from social theory to literature. One of the most important legacies of structuralism is its contribution to the development of the approaches to narratives, namely the theory of narrative, and narratology, which was first developed in the early $20^{\text {th }}$ century. Narratology is primarily interested in the general features and laws which are revealed in almost all narratives ${ }^{11}$. As Bal asserts, we cannot conceive anything beyond space and time, and the events which constitute fiction do not exist in a vacuum, but occur in historical time, and they are

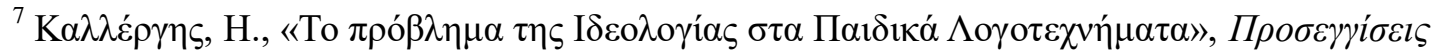

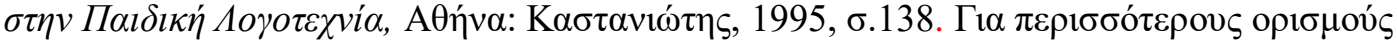

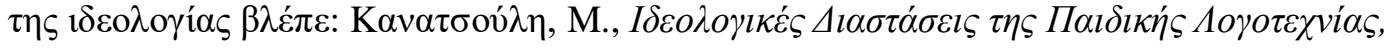

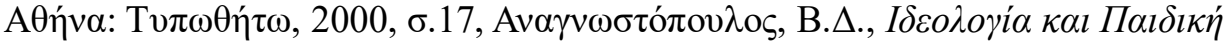

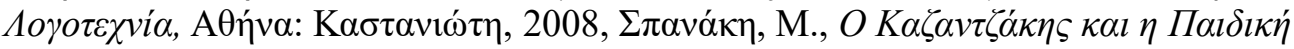

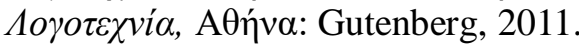

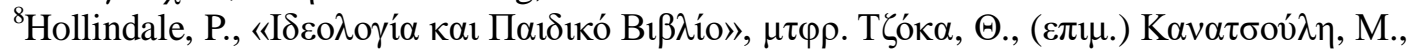
Virtual School, The sciences of Education Online, $\tau .2$ 2, $\tau \chi .1,2000$.

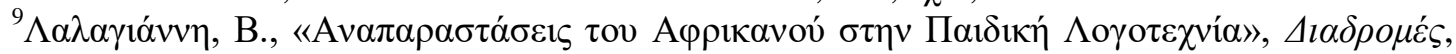

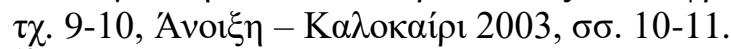

${ }^{10} \mathrm{~K} \alpha v \alpha \tau \sigma o v ́ \lambda \eta$, M., ó. $\pi ., \quad \sigma .22$.

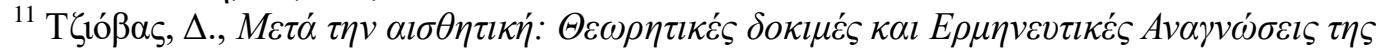

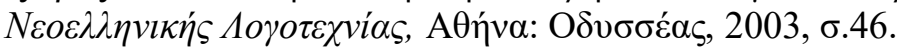


presented in chronological order and in certain space ${ }^{12}$. The events of history occur somewhere, whether this space is real or imaginary, specifically referred or not. The story is set to a specific time, mostly in the past or in the future, and in a specific space: the characters live and act in a specific place and time ${ }^{13}$.

For the analysis of the two illustrated books under discussion, we used methods from the theory of narratology. Specifically, we examined the narrative techniques found in the two texts, following the typology of Genette. ${ }^{14}$ (Genette, 1966, 1969, 1972, 1983), focusing on the organization of time. In these terms, the time of the story is considered the natural time that elapses between the events of the myth, the time at which the events occurred, or allegedly occurred. Furthermore, the time of the narrative action is considered the time when we need to read the literature text ${ }^{15}$. Genette indicates three parameters in the relations between story-time and text-time: order, duration and frequency.

Under order, Genette discusses the relations between the succession of events in the story and their linear disposition in the text. The main types of discrepancy between story-order and text-order are analepsis and prolepsis ("anachronies" in Genette's terms). An analepsis is a narration of a story-event at a point in the text after later events have been told. The narration returns, as it were, to a past point in the story. Conversely, a prolepsis is a narration of a story-event at a point before earlier events have been mentioned. The narration, as it were, takes an excursion into the future of the story ${ }^{16}$.

Under duration, Genette examines the relationship between the time the events are supposed to have taken place, and the amount of text devoted to their narration. Under frequency, Genette looks at the number of times an event appears in the story against the number of times it is narrated in the text.

\footnotetext{
${ }^{12}$ Bal, M., Narratology: An Introduction to the Theory of Narrative, second edition, TorontoBuffalo-London: University of Toronto Press, 1997, б.214.

${ }^{13}$ Buchholz, S., \& Manfred, J., «Space in narrative», $\sigma \tau$ o Herman, D., Manfred, J., Ryan, M., $(\varepsilon \pi \mu)$, Routledge Encyclopedia of Narrative Theory, London and New York: Routledge, 2005, $\sigma .552$.

${ }^{14}$ Genette, G., Narrative Discourse: An Essay in Method, $\mu \tau \varphi \rho .$, J.E. Lewin, Ithaca- New York: Cornell University Press, 1980.

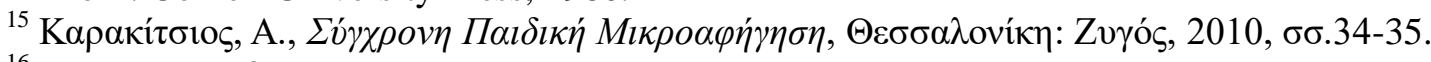

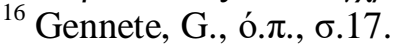


The other area of investigation that concerns us is that of the space of the other, which is studied by applying the methodology proposed by the theory of Imagology ${ }^{17}$. Ambatzompoulou emphasizes the need to consider the "space of the other" by identifying and studying precisely the contradictions inherent in the description of the "familiar" space and the space of the "other".

\section{Analyses}

"A Special Friend-it all started with a yellow bike" (2010)

The illustrated story "A special friend-it all started with a yellow bike" (2010) is a book by Anny Theochari ("a member of the Women's Literary Group"), with illustrations by Willy Karabatzia, -published by Livanis.

In this story, all events take place in a school. The protagonists are Sophie and Peter. Peter is a chubby child, and he has to live through a lot of instances of social racism acted on by his peers due to his weight. Sophie, a classmate of Peter's, turns out to be the most positive of all, and accepts him as he is in his diversity, unlike all their classmates. With her help and through his own efforts, Peter manages to prove what he really deserves from his classmates and to win the respect of all.

In Anny Theoharis' short story "A special friend-it all started with a yellow bike" (2010), the first - person narration and the visual angle of viewing and representation are created through the girl's eyes, techniques which show the child-centered dimension of the particular short story. «My name is Sophie and I am in the third grade of Primary school». The smooth course of time is violated due to the retrospective narration (analepsis or anachronies), referring to past events. Subsequently, the narration clarifies the ideological level on which she plans to make the readers think focusing on Sophie's "chubby child". It is worth mentioning that the verbal text announces in advance the relationship between the two children saying «Peter is now my best friend». In this way, she substantially gives us the end of the story. Also, it is remarkable the opposite use of the dots «But let's start from the beginning....», which separates the before-past from the after-present of the story .This

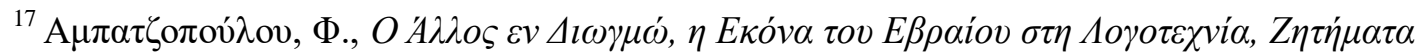

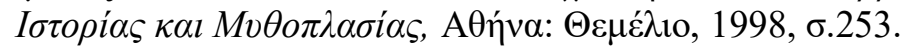


specific choice of starting the narration acts as a prologue which builds the thesis of reading and makes the reader focus on two ideological levels, obesity and otherness.

Then the plot focuses on the presentation of Peter who is taunted by the rest of the children because of his weight. When the heroine describes her new bike and the impression that it made to her friends says «Everybody wanted to ride my bike. Even Peter. I couldn't say no to him although I knew that he was too heavy to ride it». So, even Sophie discriminates Peter from the rest of the children.

The social racism, the hero suffers from, is now obvious in his school environment too where he is ruled out from his classmates' games and marginalized. Subsequently, the verbal text brings the reader into the classroom where Sophie resents with her teacher's decision to make her sit at the same desk with Peter. Through her monologue the reader watches her thoughts and feelings.

As the plot develops Sophie finds out some interesting elements of Peter's personality: «He is a clever and good student and when I wasn't aware of something Peter was the first one who helped me! He was always very generous!». Sophie helps the hero to be accepted by facing him with an honest and real way. She advises him to go in for sports to lose his extra weight and be able to withstand his volleyball team demands. However, the rest of the children react and they treat him with racism.

\section{Duration}

The time of history and the time of narration present the following relations:

- The time of narration is shorter than the time of the story in some points of the

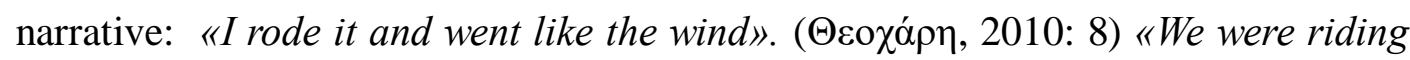

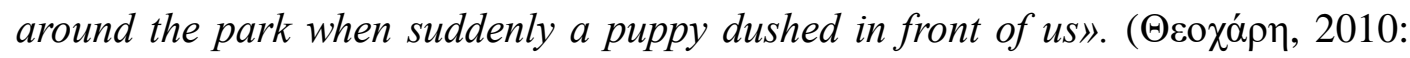
14)

- In other points the time of narration is equal to the time of story: «Hello. Is Peter

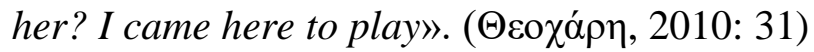


-And in some other the time of narration is longer than the time of the story, «But he is not a member of the team. Some other children shouted! Now he is! I Quit!. I

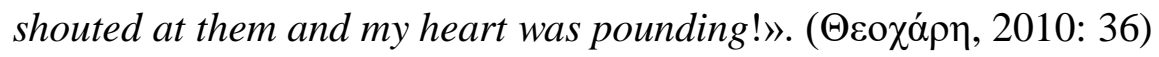

\section{The space of the "other"}

The main characters are pupils at the same school. All pupils (representing society of us) appear to spend time together, except Peter (the "other"). This is due to Peter's appearance. For most pupils, Peter is an object of contempt. His weight is enough for them to discredit his overall personality. "I couldn't say no to him, even though I

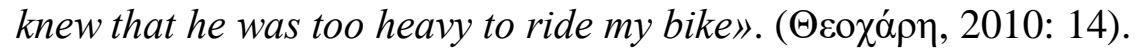

His classmate's distant demeanor leads Peter to be isolated. «His only friend was his

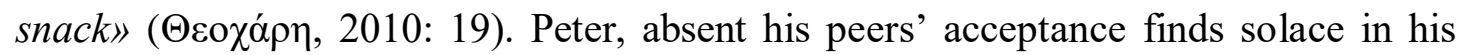
snacks, "Once I had forgotten to take my snack to school” he gave me his own half»

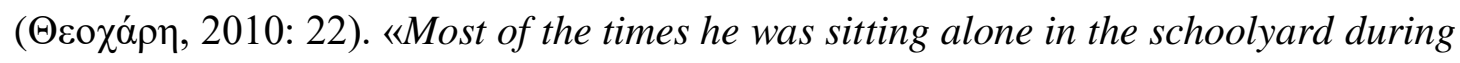

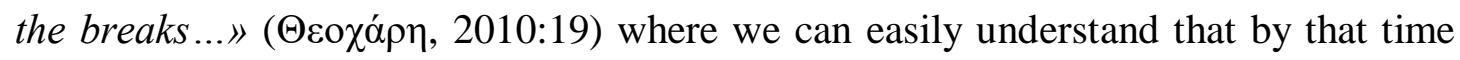
Peter felt he was not accepted, neither on the open field where children were playing football nor at the space where the girls were playing a game with a ball named "mela" ["apples"]. The space where Peter could move was more limited compared with the other children. The attitude of the dominant group, almost the entire class, towards Peter leads marginalizes him.

In the beginning, Sophie was more distant towards Peter due to an accident they had with the bicycle, "After the incident with the bike and the fall, I am ashamed of saying

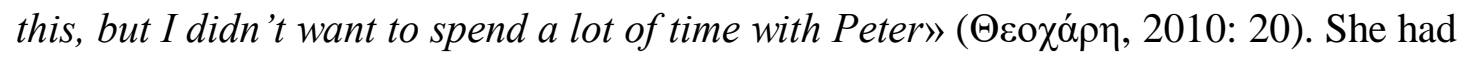
taken him on a ride but because of Peter's weight they had fallen off the bicycle.

After the intervention of the teacher who made Peter and Sophie sit together at the same desk, Sophie begins to discover positive elements in Peter's character, and as a result her behavior towards him changes. Over time, Sophie not only accepts and supports him, but also tries to help him. By trying to make Peter become good at volleyball, she helps him lose weight, which leads him to become more accepted in their small school community. We could say that Sophie fills in for the role of the 
teacher, as she is trying to facilitate relations between Peter and the other children. She is the one that helps him to integrate into the class group, by making him participate in sports and group activities.

The term racism does not only refer to discrimination related to race, skin, color, language and religion. Except these, there is also an aspect of racism which refers to the discrimination based on appearance. Among the people who face this type of social discrimination are those who experience the social problems caused by obesity, as in the Peter's case.

The community established among children is of great importance because children need each other, and because they enjoy each other's company. Friendship has been shown to be important in children's social and, cognitive affective development, interpersonal skills, and later on adjustment to social life ${ }^{18}$. The presence of friends in the child's life, and the quality of the relationships formed, not only affect the proper adjustment of the child in the developmental changes in life, such as school integration and the transition to adolescence, but also in acquiring life skills and values $^{19}$. Social exclusion is associated with children's experiences of discrimination and obstacles to participation. Friendships and supportive social relationships are critical in the lives of all children and young people, by contributing to their development, their learning, and their overall quality of life. Schools can become places where children have opportunities to acquire experiences and participate in a variety of activities to affirm social relationships, and where exclusion is recognized and denounced ${ }^{20}$.

Early childhood may be a critical period for lifelong weight control, not only because it is a time when habits are forming, but also because it is a time when most children's weight is under control and prevention strategies can work ${ }^{21}$.

\footnotetext{
${ }^{18}$ Augitidou, S., Children's Friendships in Early Schooling: Cross Cultural and Educational Case Studies, Dissertation, University of Sussex, 1995, б.1-7.

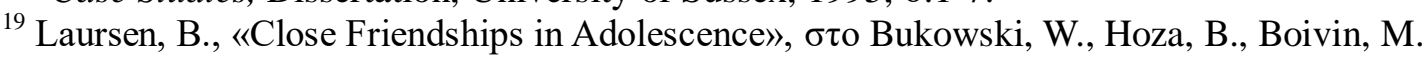
$(\varepsilon \pi u)$, Popularity, Frienship \& Emotional Adjustment During Early Adolescence, San Francisco: Jossey - Bass, 1993, бб.23-37.

${ }^{20}$ MacArthur, J., «Sustaining Friendships, Relationships, and Rights at school», International

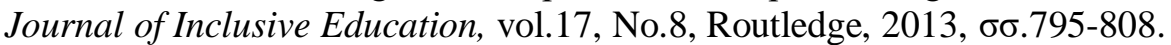

${ }^{21}$ Jalongo Renck, M., «Matters of Size: Obesity as a Diversity Issue in the Field of Early Childhood», Early Childhood Education Journal, Vol.27, No.2, 1999, б. 96-100.
} 
The author of the story ends the narration with Peter's words: «Our team may not have won the cup but I have won something more important, a true friend!»

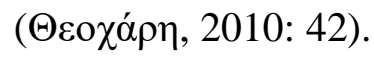

\section{“The most beautiful drawing by Marina"(2006)}

The illustrated story "The most beautiful drawing by Marina" (2006) is a book written by Katerina Papanikolopoulou and illustrated by Niki Leonidou, Taxideftis publisher $^{22}$.

The protagonist in the story is a little girl from the provinces, who moves to the city with her family, and is forced to leave behind her village, school and friends for a "better life" in the city. Marina's new life is not easy at the beginning, but soon all will find their way.

\section{Duration}

Concerning duration, Genette's second category of narrative time, the text presents deceleration particularly in a scene and there is a pause. This is a seasonal frame, a descriptive passage from a winter setting to a spring setting. For example, the main character refers to her perceptions of the habits that she had during the winter, and a description of the change of nature, where "the flower-beds were filled with flowers, the yard with grass, the trees with blossoms and there was fresh water from the spring..." in spring. In this case, time seems to stop. The young girl protagonist refers to experiencing the seasons in her village. She refers to specific nature changes from season to season.

In the illustrated short story "The most beautiful drawing by Marina" by Papanikolopoulou the narration starts when the narrator presents the heroine's way of

\footnotetext{
22 Papanikolopoulou has many years of experience with children's literature, poetry, fairytale and educational games mostly addressed at preschool children and the first grades of elementary school. Niki Leonidou is a member of the Chamber of Fine Arts, SCBWI, the IBBY and the Women's Literary Group.
} 
life in the village where she lived with her parents. More specifically she focuses on her favorite activities in school outlining the profile of a happy girl. However her everyday routine changes when she is forced to leave her village, her school, her relatives and friends for a "better life" in the city.

The new "urban" environment where she must be adapted and incorporated is completely different from the previous, "provincial" one. "She didn't want to go to school. She didn't like the yard with the gravel, not even the radiator ${ }^{23}$.The old school was in nature, while the present one is "a three floor building with many classrooms, built among blocks of flats " ${ }^{24}$. The illustration of the specific scene is representative on how different and weird the heroine feels. More specifically Marina is illustrated out of her new school without looking the audience. In the background there are high-rise buildings which remind us a concrete jungle. The vision angle of this scene is from below. According to it the element of exaggeration dominates and the sizes are extremely expanded and distorted. This illustration choice indicates the isolation and the feeling of inferiority ${ }^{25}$

The teacher's intervention, as the narration goes on, is supportive and very warm. Knowing that a new student in the class needs time to adapt, she welcomes her very friendly and with understanding. However, the protagonist chooses to isolate herself at the last desk. She writes: "She chose to sit alone in the edge of a big table». «Marina kept on sitting alone at the big table and drew almost always the same painting».

\section{Time of narration}

The narrative is presented in retrospective narration, as the facts that the writer narrates us took place in the past. When we enter the memory of a character, the order can become complex, as long as the memory of an older era could recall thoughts,

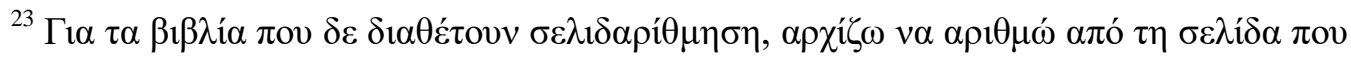

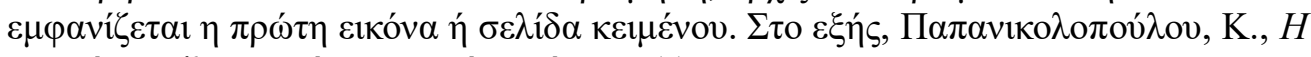

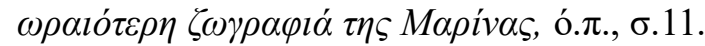

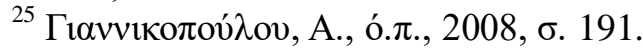


concerning even older ones and the references to the narrative "present" will be projections in the future, inside the memory ${ }^{26}$. The same thing happens in Marina's case. When she sees her new school she has a flashback to images and memories of her old school, in the village. As far as the second narrative category is concerned, the duration, the case of deceleration is applied, and more specifically in a scene, the pause version. Instead of the development of the plot, descriptions of nature are interjected. In this case time seems to stop.

\section{The space of the "other"}

The events of the story initially take place in the space of the "other" as per the children in their school class. "Marina's village is perched on the

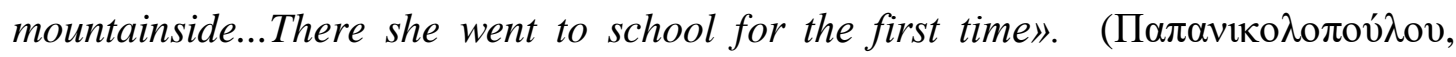
2006:1). An explanation is given for the change of place. After an unexpected turnout, «Her dad got a job in town. The whole family had to move soon»

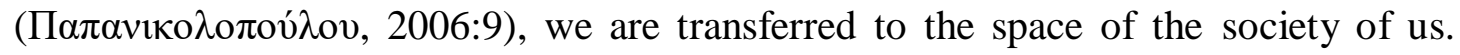
"The city school was a three-floor building with many classrooms, built among blocks

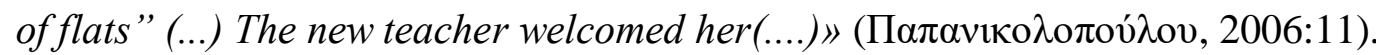

Marina is first introduced in the company of her classmates in the village school. But the inevitable departure from the village, and her coming to the city, change how she feels. Her new school looks so different, something that fills her with fear: «How

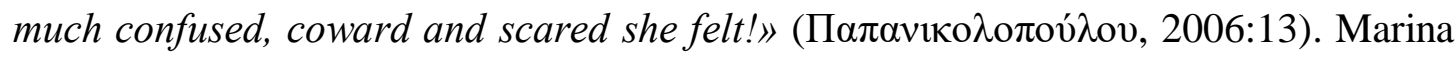
feels that her new classmates do not understand her, and their laugher when she presents her drawing make her feel even more alone: "Marina was annoyed by their laughs. She wanted to run, to go away front these kids who didn't understand her at

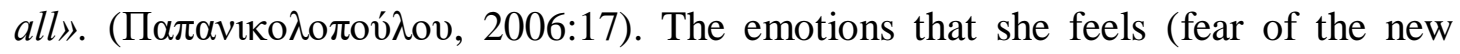
environment, sadness for what she left behind) made her "shrink" as she is unable to handle this new situation. For this reason, Marina imprints herself as an ant in her drawing, and draws the other children as incomprehensible shapes.

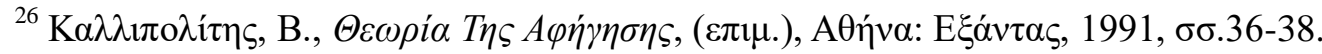


As the story unfolds, the relationships restore quickly. Her classmates begin to understand how she feels through her drawings, which in turn leads them to make them want to get to know her better: "They all gathered around Marina. They wanted to learn more about it, and not just about it. They wanted to learn more about

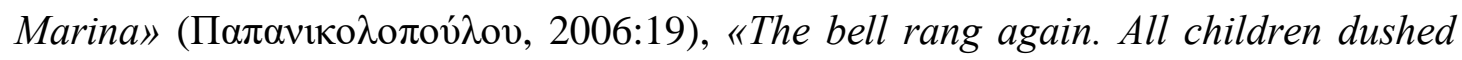
happily in the yard. Marina was there too with her new friends».

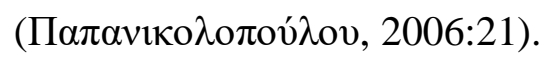

Drawings are one of the most important means of child psychotherapy, because they can mobilize creativity, stimulate self-confidence and help "recuperate" from negative feelings. From a sociological point of view, a child's drawing shows her gradual adjustment and her integration, to the new school and, community. Children's drawings in this instance, as in many other cases reflect the child's experiences ${ }^{27}$. Drawing is recognized as one of the most important means of expression for children, and has repeatedly been associated with capturing their personality and their emotions, as in the case of Marina, who is expressing her fear of, coming to a new school, through her drawings. Through the "space" of her drawing, she is trying to adjust to the new environment, which is the "space" of the school.

From a pedagogical point of view, children's drawing and pictures are valuable means of diagnosing the mental world of the child. To some extent, it could be argued that it is a screen on which the child displays his inner-mental world ${ }^{28}$.It is a special "writing" for the child, a "writing" that evolves along with the sensory powers and his knowledge ${ }^{29}$.

Child drawing appears to serve at other levels of expression of the child. ${ }^{30}$ As part of a therapeutic process, drawing is a means for the child to cope with insecurities, and painful experiences, and to solve problems. In the case of Marina, painting helps her remember, her village and how confused she feels.

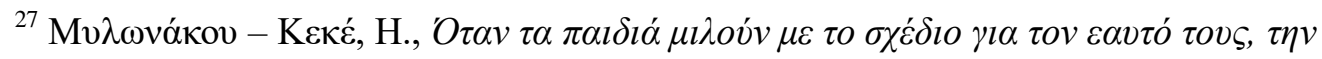

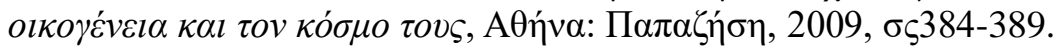

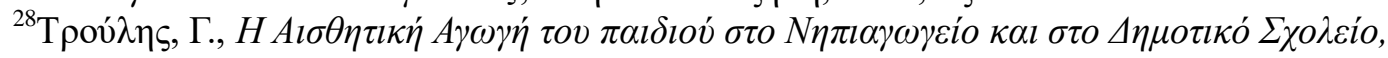
A $\theta \dot{v} v \alpha, 1991, \sigma \sigma .83-84$.

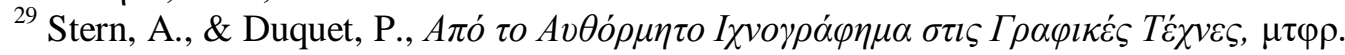

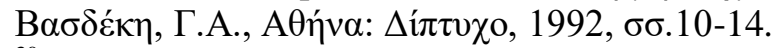

${ }^{30}$ Arheim, R., Art and Visual Perception. A Psychology of the Creative Eye, Berkeley, University of California Press, 1974.
} 
In this book there is evidence of social concern which operates indirectly, and which is connected with the general issue of adjusting children that come from other countries. Marina's case, coming from her village to a new school environment in the city, reflects the same difficulties faced by children who come from families of immigrants and refugees, in order to become integrated or to coexist in Greek society. For example, in the story of a little girl called Faouzegia, from the illustrated book, entitled "And the stories immigrate" (2009) by Iliopoulos Vangelis (Patakis editions), the protagonist lives happily in her country, from where she forced to leave, due to her parents' unemployment. Life in the urban environment of Athens disappoints her and she encounters several difficulties. In the final page of the book we read about Faouzegia's process of adjustment to a new country, from her native Egypt to Greece.

These books realistically represent stories of little children who come to a new environment. Changing places appear to be of equal importance to child psychology, whether it is about moving from the village to the city, or from one country to another. The representations of the protagonists suggest situations from the modern multicultural reality of the Greek society. The two books reflect the initial difficulty that pupils ought to accept and understand each other, despite their choices and their differences. Later, of course, everything changes through a gradual process of acquaintance, contact, communication and coexistence with the other.

In modern multicultural societies, the conversation with the "other" is indispensable to human reality. Today we know that diversity is an asset for all societies. It is important that children are exposed to multicultural children's literature so that they are given the opportunity to explore the heritage and values of the variety of people living in their society, and perhaps shed some of their preconceived notions and negative attitudes toward others ${ }^{31}$. Moreover, it is an appropriate means of building respect across cultures ${ }^{32}$.

\footnotetext{
${ }^{31}$ Barroqueiro, D., \& Sprouse, S., «The Interplay of Text and Images send meaningful messages to children», The Journal of Multiculturalism in Education, vol.8, October, 2012, $\sigma \sigma .3-4$.

${ }^{32}$ Norton, D., ó. $\pi ., \quad \sigma .502$.
} 


\section{In conclusion}

In summary, we could note that through analysis of time in the two narratives discussed, two stories that explored children's lives and societal concerns and main characters emphasized a diversity of the "other": in the first story, Peter's obesity and in the second, Marina's change of place and feelings of loneliness. The characters in these stories have to cope with experiences of exclusion and loneliness before the people around them learn that difference and diversity do not change the fact that all humans are worth the same. More specifically, the analysis of the space of the "other" was shown in the context of school life, as the two Greek narratives take issue with contemporary realities and diversity. We could say that it is necessary to point out the issue of diversity from the very first reading experiences offered to young children, so as to gradually refute any stereotypes and prejudices that exist in society with respect to different people. 


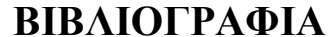

Augitidou, S., Children's Friendships in early schooling: cross cultural and educational case studies, dissertation, University of Sussex, 1995, б.1-7.

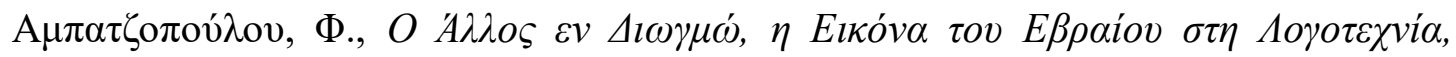

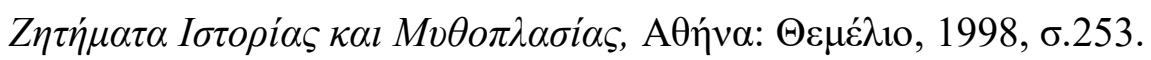

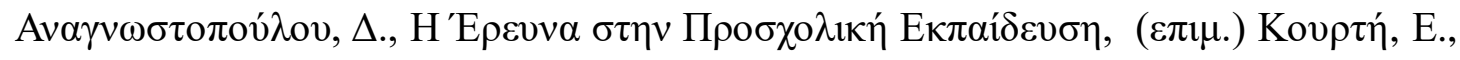
$\tau . \mathrm{A}, \mathrm{A} \theta \dot{v} \vee \alpha:$ Тv $\pi \omega \theta \dot{\tau} \omega, 2001, \sigma \sigma .118-119$.

Arheim, R., Art and Visual Perception. A Psychology of the Creative Eye, Berkeley, University of California Press, 1974.

Barroqueiro, D., \& Sprouse, S., «The interplay of text and images send meaningful messages to children», The Journal of Multiculturalism in Education, vol.8, October, 2012, $\sigma \sigma .3-4$.

Bal, M., Narratology: An Introduction to the Theory of Narrative, second edition, Toronto-Buffalo-London: University of Toronto Press, 1997, б.214.

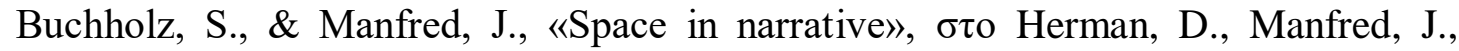

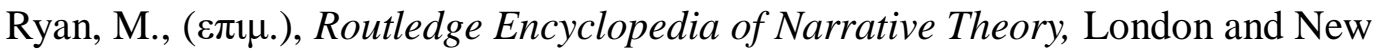
York: Routledge, 2005, б.552.

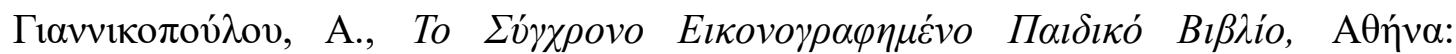

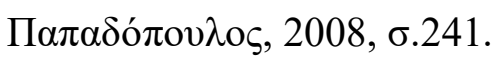

Ciancolo, P., Illustrations in Children's Books, Dubuque, Iowa, WM.C Brown Company Publishers, second edition, 1976, бб.94-95.

Genette, G., Narrative Discourse: An Essay in Method, $\mu \tau \varphi \rho .$, J.E. Lewin, IthacaNew York: Cornell University Press, 1980.

Hunt, P., Literature for Children, Contemporary Criticism, London: Routledge, 1992, $\sigma .18$.

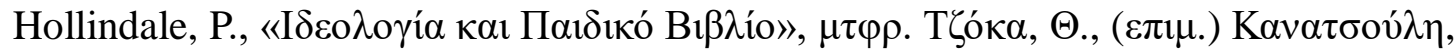
M., Virtual School, The sciences of Education Online, $\tau$. 2, $\tau \chi .1,2000$. 


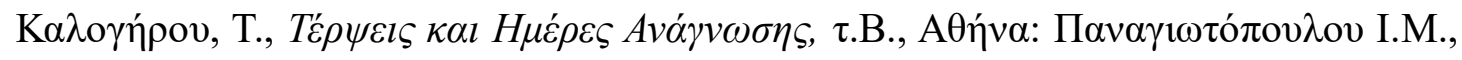
2003, б.61.

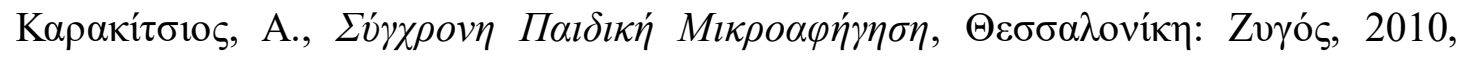
$\sigma \sigma .34-35$.

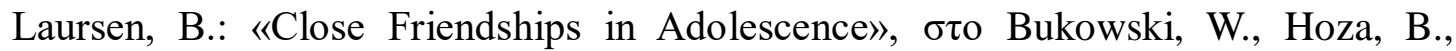

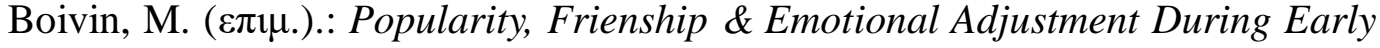
Adolescence, San Francisco: Jossey - Bass, 1993, бб.23-37.

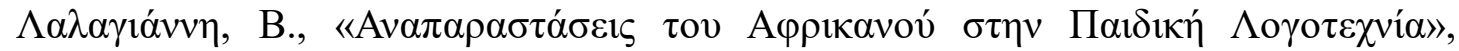

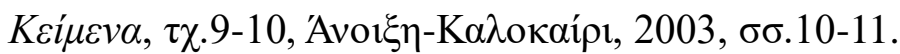

Marshall, M., An Introduction to World of Children's Books, $2^{\text {nd }}$ edition, Gower, 1988, $\sigma .42$.

MacArthur, J., «Sustaining Friendships, Relationships, and Rights at School», International Journal of Inclusive Education, vol.17, No.8, Routledge, 2013, $\sigma \sigma .795-808$.

Nodelman, P., Words about pictures. The Narrative Art of Children's Picture Books, Athens and London, The University of Georgia Press, 1988, б.1.

Norton, D., Through the Eyes of a Child: An Introduction to Children's Literature,

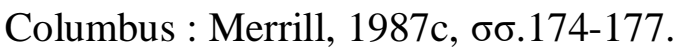

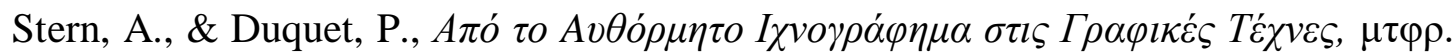

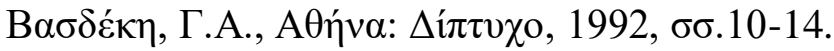

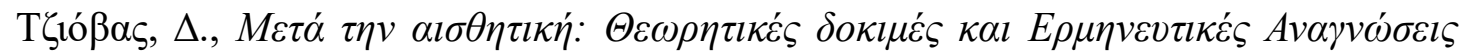

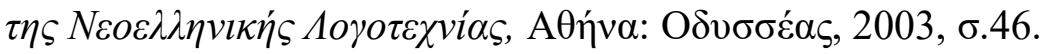

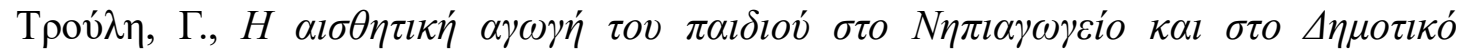

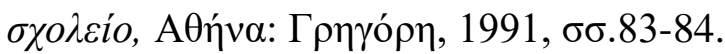

Jalongo Renck, M., «Matters of Size: Obesity as a Diversity Issue in the Field of Early Childhood», Early Childhood Education Journal, Vol.27, No.2, 1999, б. 96-100. 


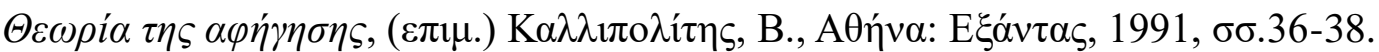

